\title{
Stem Gall Disease of Coriander: Causes and Integrated Management
}

\author{
Preeti Verma, Mohan Lal Yadav*, C.B. Meena and D.L. Yadav \\ Agricultural Research Station, Agriculture University, Kota, India \\ *Corresponding author
}

\begin{tabular}{|c|}
\hline Keywords \\
\hline $\begin{array}{l}\text { Coriander, Stem } \\
\text { gall, Causes and } \\
\text { integrated } \\
\text { management }\end{array}$ \\
\hline Article Info \\
\hline $\begin{array}{l}\text { Accepted: } \\
30 \text { October } 2019 \\
\text { Available Online: } \\
10 \text { November } 2019\end{array}$ \\
\hline
\end{tabular}

\section{A B S T R A C T}

Coriander is important seed spices crop and 95 percent cultivation under South Eastern part of Rajasthan. Stem gall is hot spot in this part as well as reduced quality and quantity of crop. 50\% loss in yield occurs due to this disease in Kota, Bharatpur, Dholpur, Sawai Madhopur and adjoining areas in Rajasthan. The flowering stage of the crop is to be more sensitive to the damage caused by the disease. The disease appears in the form of tumour like swellings on stem, leaf, peduncle, flowers and fruits. Variety $\mathrm{ACr}-1$ released in the year 2016 from National Research Centre on Seed Spices, Ajmer has been reported to be absolutely resistant to the disease. Minimum disease incidence was recorded by seed treatment of hexaconazole $(0.2 \%)$ and foliar spray of hexaconazole $(0.2 \%)$ after 40,60 and 75 days of sowing. Seed treatment of propiconazole $(0.2 \%)$ and foliar spray of propiconazole $(0.2 \%)$ after 40,60 and 75 days after sowing also controlled the disease.

\section{Introduction}

Coriander (Coriandrum sativum $L$ ) is one of the first seed spices used by mankind and widely cultivated across the world and the country for its leaves and seed used for flavouring and seasoning of the food and food products. India is the biggest producer, consumer and exporter of coriander in the world. Besides its domestic consumption, the surplus produce is used for export to earn foreign exchange to an appreciable amount. It is one of the major spice crops of India (Leharwan and Gupta, 2019). South Eastern Rajasthan comprising of districts of Kota, Bundi, Baran and Jhalawar covered under zone- $\mathrm{V}$ is the major producer of the crop, contributing around 98 percent to the total area and production of the state. The productivity of the crop in the country has shown an increasing trend in the late past from $514 \mathrm{~kg} / \mathrm{ha}$ in the year $1997-98$ to $806 \mathrm{~kg} / \mathrm{ha}$ in the year 2007-08. The productivity of the crop in the state and south eastern part has also 
shown a similar trend as it has risen from 1106 $\mathrm{kg} / \mathrm{ha}$ in the year 2010-11and1230 kg/ha in the year 1011-12. But there has been a reduction of 35 percent in the productivity of the state and zone during the period i.e. 641 to 797 $\mathrm{kg} / \mathrm{ha}$ from 2012 - 2015. An insight into the causes of this productivity drop indicates that stem gall disease had been the major factor of reduced crop yield and productivity besides adverse climate and erratic rainfall during these years. Stem gall caused by the fungus Protomyces macrosporus L. is a serious disease of coriander damaging all the aerial plant parts incurring heavy losses as the market value is reduced. In India, stem gall disease of coriander was reported for the first time from Pusa (Bihar) by Sydow and Butler (1911). Later, Gupta (1954) found this disease to be very common in the northern part of Madhya Pradesh and adjoining districts of Rajasthan and Uttar Pradesh. Protomyces macrosporus is an ascomycete fungus that forms galls on Aegopodium podagraria, Anthriscus sylvestris, Angelica sylvestris, Daucus carota and some other members of the family Umbelliferae or Apiaceae, commonly known as umbellifers (Margaret and Shirley, 2002). The $P$. macrosporus has a complex life cycle including ascospores and chlamydospores. Stem gall is dreadful disease in South Eastern Rajasthan and difficult to manage by one component, therefore, it needs thorough understanding of the diagnostic characters of the disease, control measures, environmental factors, infection chain etc. for disease control as well as maintaining quantity and quality of coriander.

\section{Losses due to stem gall in coriander}

Losses in coriander due to stem gall depend upon the locality, time of infection, cultivar, control measures and environmental conditions. Coriander suffers from various fungal diseases of which the stem gall disease caused by Protomyces macrosporus is the most destructive and versatile disease (Bilgrimi, 1991). Losses due to stem gall are threatening to the farmers as infected fruits lose their value for consumption and as propagules. Disease intensity of stem gall to the extent of 23 percent in coriander fields in Gwalior resulted in a 15 percent yield loss (Gupta, 1954). Singh et al., (1984) observed 7.5 to $24.4 \%$ disease intensity during survey of coriander fields in seven districts of Uttar Pradesh. The disease manifests itself in the form of galls on stems, branches, leaves, petioles and fruits, causes 15-20 per cent yield loss (Pandey and Dange, 1998). Malhotra et al., (2016) also observed 15 percent fruit yield loss when about 23 percent plants were infected. While, Mishra and Pandey, (2017) reported 33-36\% yield loss due to stem gall. However, Sandeep et al., (2019) reported 20.8 percent yield losses in eastern part of Uttar Pradesh due to stem gall disease. A preliminary survey has shown that more than $50 \%$ loss in yield occurs due to this disease in Kota, Bharatpur, Dholpur, SawaiMadhopur and adjoining areas in Rajasthan recorded by Smita Jain (2018).

\section{Symptoms}

The symptoms first appear in the form of galls on the lower part of stem which gradually extends upwards and finally the whole plant becomes infected. The infected seeds become hypertrophied depending upon the stage of infection which ultimately lowers the crop yield and quality (Khan and Parveen, 2016). As per Pandey and Dange, (1998) the disease appears in the form of tumour like swellings on stem, leaf, peduncle, flowers and fruits. In instances of infection in inflorescence seed grain production is drastically reduced causing colossal loss to the crop. Severely infected plants loss their vigour and are deformed in their vegetative and reproductive growth forms. Infection occurs during January to March, when winter rains occur and foggy 
conditions prevail in the atmosphere. The disease appears in cold and humid conditions in the field (Smita Jain, 2018).

\section{Host range}

The family Umbelliferae which is susceptible to Protomyces spp. such as Aegopodium, Ammi, Angelica, Anthriscus, Archangezica, Athamanta, Canopodium, Carum, Caucazis, Chaerophyzzum, Coriandrum, Feruza, Heraczeum, Hydrocotyze, Laserpitiwn, Ligusticum, Meum, Onanthe, Pancicia, Parum, Peucedanum, Pimpineua, Seseli, Silaus, ThapsiaandTrinia reported by Reddy and Kramer (1975).

\section{Biochemical analysis}

Biochemical studies of plant pathogen interaction revealed that soluble sugar, starch, chlorophylls, phenolic and tannin content were observed at higher level in healthy leaves compared to pathogen infected leaves (Anjum et al., 2012). Mishra et al., (2017) revealed that total phenol content was highest in healthy plant parts as compared with stem gall infected plant parts. The stem gall disease markedly decreased total phenol content in all parts of coriander. Sandeep et al., (2019) revealed that soluble sugar, starch, chlorophylls, phenolic and tannin content were observed higher level in healthy leaves compared to pathogen infected leaves.

\section{Epidemiology}

Weather conditions play a predominant role in determining the progress and severity of epidemics. Mukhopadhyay and Pavgi (1971) found that the primary inoculum of the disease is carried to the field with the seed drawn from an infected crop, crop debris and uncleaned seed mixed with fruit galls. The pathogen persists from year to year in the chlamydospore stage and the latter germinates to initiate fresh infection in the following season. The thick-walled chlamydospore resists the effect of high temperature and desiccation during the high-temperature summer months (May-June) and survives the unfavorable environment over prolonged periods in the absence of the host crop. The chlamydospores hibernating in the crop debris and/or hypertrophied fruit galls are released after the monsoon period (July-September) in the former case and the richly irrigated fields with heavy soil in the latter. The chlamydospores from fruit galls are induced to germinate on the soil surface late in January at cool time. Malhotra et al., (2016) observed that presence of excess soil moisture, low sunshine hours due to cloudy weather in winter season fuels the spread of stem gall and damages the crop. 45 percent of soil moisture level was favorable for disease development and resulted in 70.25 percent disease incidence and 35.25 percent disease severity.

Severity of stem gall disease has been significantly influenced by dates of sowing. Early and late sowings (16 ${ }^{\text {th }}$ Sept.-16 Dec.) exhibited significantly less mean disease severity (14\% and $10 \%)$ as compared to other dates. Least disease has been recorded in crop sown on Dec. $1^{\text {st }}$ but it affected seed yield adversely. Plant sown on Nov. $16^{\text {th }}$ showed comparatively low intensity (17\%) of stem gall and significantly higher seed yield (Tripathi, 2003). Lakra, (2000) also reported that in Sept. and Dec. sown crop of coriander, stem gall infection remained at low profile but also gave less yields.

A positive and significant correlation coefficient $(\mathrm{r}=0.73)$ occurred between disease intensity and per cent seed yield loss. Severity of the disease has been reported in irrigated soils and low temperature. Infection has been observed to be minimum at low soil $\mathrm{pH}$ (3- 6) while the maximum infection has been found on the roots at higher $\mathrm{pH}$ of 7-8.5. 
Increasing level of humidity, intensifies the effect of this disease on crop.

\section{Causes and management}

\section{Excess plant population}

Coriander shows slow, uneven and less germination. The minimum standard for germination is only 65 per cent and hence, there's a common practice among the farmers, of using more than recommended seed rate. Where the recommended seed rate is $15-20 \mathrm{~kg}$ per hectare only, the farmers generally use 30 $\mathrm{kg}$ seed per hectare i.e. around 50 percent more seed. Overcrowding of the plants results in overshadowing restricting the sunlight to the plants specially to the basal part or the part near to the ground and creates humid conditions favouring the development of disease indirectly and therefore, can be said to be one of the reason for the disease. Therefore, optimum plant population should be maintained by adopting recommended seed rate and plant spacing and thinning at 45 days after sowing, if required. The plants after thinning can be used for sale as a green as an additional source of income.

\section{Water stagnation}

Standing water near the bunds or any low lying areas of the field also creates humidity and anaerobic conditions conducive for the appearance of the disease. In general also, the water requirement of coriander is not much high, only two irrigations are required at critical stages of crop growth and development depending on the agroclimatic conditions, soil moisture level, and the variety used. Therefore, over watering should be avoided and irrigation should be applied precisely and utmost care should be taken to avoid water logging in the field by adopting proper drainage measures.

\section{Infected / diseased seed}

Stem gall is a seed borne disease and using diseased seed for sowing is an easy approach for appearance of the disease. Keeping in view the nature of the disease, seed treatment with any systemic fungicide is mandatory before sowing. Diseased plants as and when found, must be uprooted and thrown outside the field.

\section{Infected field}

If coriander is grown at the same site in the same field and the disease appears in the crop continuously over the years, the field becomes infected with the fungal pathogen due to its continuous multiplication in its preferred host crop. Even the healthy fields can also become infected due to sowing of the diseased seed in the field over the years. Therefore, crop rotation assumes great significance in such conditions and rotation of coriander with other non-host winter (Rabi) crops is one of the best ways to avoid the disease incidence. Besides this, deep summer ploughing should also be done to kill the resting spores.

\section{Sowing time}

The flowering stage of the crop is said to be more sensitive to the damage caused by the disease. The appearance of the disease generally coincides with the continuous winter rains during the months of January-February. The prolonged cloudy, foggy weather with high humidity and absence of sunlight provides congenial conditions for disease development. If the crop is sown early or timely during the month of October, it is at flowering stage at this time and more damage is observed in the crop. It's a general observation at the farmers' field that the late crop sown in last week of November or first week of December generally escapes the disease. Verma et al., (2017) also reported that best time for sowing of coriander is between 
$30^{\text {th }}$ October- $15^{\text {th }}$ November to achieve high yield and less disease incidence. However, the yield levels of the late sown crop is lower than the timely sown crop but in the event of complete failure of the timely sown crop due to disease, the farmer can harvest significant yield by late sowing.

\section{Essential oil content}

Coriander seed contain essential oil responsible for its aroma and quality. Certain accessions of coriander having higher essential oil content have been observed to be severely affected by stem gall disease indicating probably, a positive correlation between stem gall susceptibility and high essential oil content. Such linkages of desirable and undesirable traits may be broken by using classical breeding techniques such as bi parental matings and disruptive selection (Kalra et al., 2000). However, such a strong positive correlation between high quality (high essential oil) and disease susceptibility need not be true for all the accessions or genotypes. Therefore, larger number of germplasm accessions need to be evaluated for essential oil content and disease incidence to work out the correlation between the two parameters.

\section{Integrated Disease Management}

\section{Resistant cultivars}

To control diseases in a crop the best way is to have varieties resistant to pathogens causing diseases. Use of varieties resistant to stem gall for cultivation is the easiest, feasible, cheap and ecofriendly approach to combat the disease and achieve higher yields. Khan and Parveen (2016) screened 27 varieties against stem gall disease and none of the variety was found free from stem gall infection, while four varieties viz., UD-125, UD-317, UD-749 and $\mathrm{RCr}-480$ had less than $10 \%$ disease intensity and were thus graded as resistant (1-10\% disease intensity). However, Kalra et al., (2000) reported only two varieties (C-1 and Pant-1) out of sixteen selected to be highly resistant against the disease. Recently, a new variety ACr -1 released in the year 2016 from National Research Centre on Seed Spices, Ajmer has been reported to be absolutely resistant to the disease both at experimental as well as farmers field. This can be a boon to the coriander farmers especially of zone- $\mathrm{V}$ of Rajasthan state which contributes 98 percent to the total area and production of the crop in the state. Besides this, RD-385 (Rajendra Dhania-1) recently released from Dholi, Bihar has also been reported to be moderately resistant to stem gall disease. The cultivation of these high yielding, resistant varieties will certainly prove profitable for the coriander growers.

\section{Cultural method}

Butler (1918) reported that disease incidence can be reduced by removal and destruction of gall bearing parts of the plant. All the infected plants should be uprooted and burnt. It has been observed that early and late sown crop contracted less incidence of stem gall than normal sown crop (Lakra, 2000; Tripathi, 2003). The disease can be reduced or controlled by some cultural practices such as: use of clean and healthy seeds, proper field sanitation - field should be kept clean, removal and destruction of the diseased plants, soil solarization, crop rotation - crop should be rotated for long term with other crops belonging to other family to reduce the primary inoculum. In the presence of excessive soil moisture, especially under shaded conditions, when the stem fails to harden and remain succulent, the tumors are numerous. Since environmental conditions like temperature and humidity are important factors for disease appearance or development, therefore stem gall disease can also be managed by adjusting the time of sowing 
according to the environmental conditions. Experiments have been conducted to work out the most suitable time of sowing for achieving high yield without crop loss due to disease. It has been recommended that coriander sown $30^{\text {th }}$ October to $15^{\text {th }}$ November gives highest seed yield. Early sown crop in mid-September and late sown crop around first week of December have less disease severity, however the crop sown in mid-November had least intensity of the disease and high seed yield (Tripathi, 2003). Potassium and nitrogen fertilizers reduced stem gall incidence while phosphorous fertilizers increased the disease (Tripathiet al., 2002).

\section{Biological control}

Management through biocontrol agents offers an economic and ecologically sustainable approach towards disease control. Trichoderma spp. have been found most effective mycoparasites in the management of soil borne fungal pathogens, because of its ability to survive under a wide range of climatic conditions(Pan and Bhagat,2008). Dabbaset al., (2010) reported an improvement in yield and reduction in stem gall intensity of coriander with seed and soil treatment of $T$. viride. It has been reported that Trichoderma spp. produce plant growth promoting factors and secondary metabolites which may act as auxin like compounds due to which enhancement of plant growth occurs (Vinale, et al., 2008). The results revealed that, application of biocontrol agents / botanicals both alone and in combination caused significant reduction in stem gall intensity (20.33-84.82\%) as compared to control. Among the tested biocontrol agents, T. viride was found superior in enhancing the growth and yield as well as reduction in stem gall intensity (44.37\%). Application of biocontrol agents in soil supplemented with botanicals was found more beneficial in enhancing plant growth and yield attributes as well as reducing stem gall intensity (52.54-84.82\%). Among various combinations tested, $T$. viride + Melia azedarach and $T$. viride+ E. globulus caused greater increase in plant growth and yield contributing characters both in pathogen inoculated as well as uninoculated plants (Khan and Parveen, 2018). Dabbas et al., (2009) recommended seed treatment with $T$. viride $4 \mathrm{~g} / \mathrm{kg}$ seed + soil treatment by $T$. viride $2 \mathrm{~kg} / \mathrm{ha}$ for the management of stem gall of coriander. Similarly, Kumar et al., (2014) found that the seed treatment of bio-fungicides like T. viride and Pseudomonas at the rate of (0.4\%) and foliar spray of Trichoderma spp. and Pseudomonas spp. at the rate of $(0.4 \%)$ after 40,60 and 75 days of sowing decreased the percentage incidence of disease by 24.50 and 32.65 , respectively.

\section{Chemical control}

Nene et al., (1966) reported for the first time that it has been possible to obtain at least a partial field control of this disease, through seed treatment with thiram at the dose of 0.25 $\mathrm{kg}$ per $100 \mathrm{~kg}$ of seed. Bhardwaj and Shrestha (1985) reported that four foliar sprays of thiram 0.2 , captafol 0.2 and carboxin $0.1 \%$ at fortnightly intervals from the time of disease infestation was found to be more effective or effective than seed treatment or combined seed and soil treatment in controlling stem gall and also increased seed yield. Kumar et al., (2014) reported that minimum disease incidence of 44.16 percent was recorded by treatment of seeds with hexaconazole $(0.2 \%)$ and foliar spray of hexaconazole $(0.2 \%)$ after 40,60 and 75 days of sowing. Disease incidence of 48.33 by seed treatment of propiconazole $(0.2 \%)$ and foliar spray of propiconazole $(0.2 \%)$ after 40,60 and 75 days after sowing and controlled the disease by 40.82 percent over control. In the wake of excessive and continuous rains during the cropping (flowering) season of coriander and ultimately occurrence of disease in severe 
form during the recent past years, certain new chemicals have also been recommended after thorough testing at experimental as well as farmers' fields. Propiconazole, hexaconazole and tebuconazoleat the concentration of 0.2 per cent have been proved to be quite effective for the control of disease (Verma et al., 2017).

Looking to the various environmental (above and below surface) and seed factors responsible for the severity of the disease, it becomes imperative to adopt control measures in an integrated approach to keep the appearance of the disease below economic threshold level to sustain the production and productivity of the crop in the zone and the country, as well as for the maintenance of the crop quality.

\section{References}

Bilgrimi K.S., Jamaluddin, M.A. Rizvi, Fungi of India-lists and References, Today and Tomorrow's Printers and Publishers, New Delhi, 1991 pp. 798.

Dabbas, M.R., Singh, D.P. and Prakash, H.G. (2009). Management of stem gall of coriander through IDM practice. Intern $\mathbf{J}$ Pl Protec, 2: 255-257.

F. Vinale, K. Sivasithamparam, E.L. Ghilasberti, R. Marra, M.J. Barbeeti, Trichoderma secondary metabolites in the interactions with plants, Physiol. Mol. Plant. Path, 72(2008): 80-86.

Gupta, J.S. (1954). Disease appraisal of stem gall of coriander. Indian Phytopath, 7:53-60.

Singh, H.B., A. Singh, A. Tripathi, S.K. Rai, R.S. Katiyar, J.K. Johri, S.P. Singh. Evaluation of Indian coriander accessions for resistance against stem gall disease. www.academicpub.com/ map/items/849216.html.

Jain Smita 2018. in vitro studies on dual culture of Protomyces macrosporus on Coriandrum sativum. International Research Journal of Natural and Applied Sciences, Volume 5, Issue 4, pp 118-
132.

Kalra et al., Khan and Parveen (2016). Screening of Some Recently Developed Coriander Varieties against Stem Gall Disease Caused by Protomyces macrosporus. J Plant PatholMicrobiol 2016, 7: 8.

Khan, M.R., and Parveen, G. (2016). Screening of some recently developed coriander varieties against stem gall disease caused by Protomyces macrosporus. 7:8 doi: 10.4172/2157-7471.1000373.

Kumar Sandeep, Chaudhary VP, Singh Veer and Kumar Krishna (2019) Biochemical changes in coriander plant parts infected by stem gall disease caused by Protomyces macrosporus. International Journal of Chemical Studies; 7(1): 21962199.

Kumar, G., Yadav, S.K., Patel, J.S., Sarkar, A. and Awasthi, L.P. (2014). Management of stem gall diseases in coriander using Pseudomonas and Trichoderma (bioagents) and fungicides. J Pure ApplMicrobio, 8:1-4.

Kumar, G., Yadav, S.K., Patel, J.S., Sarkar, A. and Awasthi, L.P. (2014). Management of stem gall diseases in coriander using Pseudomonas and Trichoderma (bioagents) and fungicides. J Pure Appl Microbio, 8:1-4.

L.N. BhardwajandS.M. Shrestha (1985). Efficacy of fungicide application in the control of stem gall of coriander. Agriculture, Ecosystems \& Environment Volume 13, Issues 3-4, Pages 319-323.

Lakra, B. S. (2000). Management of stem gall of coriander (Coriandrum sativum) incited by Protomyces macrospores. Indian Journal of Agricultural Sciences. Vol. 70 No. 5 pp. 338-340.

Lakra, B.S. (1999). Assessment of losses due to stem gall of coriander. Pl Dis Res, 14:85-87.

Leharwan M, Gupta M. (2019). Stem Gall of Coriander: A Review. Agri Revs, 40(2):121-128.

M.R. Dabbas, D.P. Singh, H.G. Prakash, Management of stem gall of coriander 
through IDPM practice, Int. J. Plant Prot. 2(2): (2010) 255-257.

Malhotra, S.K., Kakani, R.K., Sharma, Y.K. and Singh, D.K. (2016). Ajmer coriander1(NRCSS, ACR-1) resistant to stem gal disease- an innovative farming technology. Indian J. Arecanut, Spices Medic. Pl. 18:1-7.

Manzoor R. Khan*, GhazalaParveen 2018. Supplementing biocontrol agents with botanicals improved growth and yield of coriander (Coriandrum sativum L.) infected with Protomyces macrosporus Unger. Current Plant Biology 15 (2018) 44-50.

Margaret Redfern and Peter Shirley (2002). British Plant Galls. Identification of Galls on Plants \& Fungi. Shrewsbury: Field Studies Council. p. 222.

Mehrotra, R.S. and K.R. Aneja (1990). "Ascomycotina". An Introduction to Mycology. New Age International. pp. 251-430.

Mishra R. S., Kumar Sandeep, Pandey V. P. and Pathak S. P. 2017. Effect of Stem Gall Disease Caused by Protomyces macrosporus on Biochemical Changes of Coriander. Int. J. Pure App. Biosci. 5(2): 690-699.

Mishra R.S. and Pandey V.P. 2017. Effect of organic treatment on stem gall disease, growth and yield of coriander. Academy of Agriculture Journal, Vol.2, Issue.8, Pp. 79-89.

Mukhopadhyay, A.N. and Pavgi, M.S. (1971). Environment in relation infection of coriander by Protomyces macrosporus Unger. Ann Phytopath Soc Japan. 37: 215-219.
Nene, Y.L., Siddiqui, I.A. and Kharbanda, P.D. (1966). Control of stem gall of coriander by fungicides. Mycopathologia Mycologia Applicata 29:142-144.

Pandey RN, Dange SRS. Diseases of coriander and fennel- a review. Agricultural Review Karnal. 1998; 19(2):120-125.

Reddy, M.S. and Kramer, C.L. (1975). A taxonomic revision of the Protomycetales. Mycotaxon 3: 1-50.

S. Pan, S. Bhagat, Characterization of antagonistic potential of Trichoderma spp. against some soil borne plant pathogens, Zhongguo Mei Jie Sheng Wu XueJi Kong ZhiZaZhi 22 (2008) 43-49.

Singh S.P., Gupta J.S. and Sharma A. K. 1984. Disease appraisal and crop loss estimates in coriander attacked by Protomyces macrosporus Onger in Uttar Pradesh Geobios 11: 276 -78.

Sydow, H. and Butler, E.J. (1911). Fungi India eorientalis. Ann Mycol, 9:372-421.

Tripathi, A.K. (2003). Effect of sowing dates and weather parameters on stem gall disease of coriander. Indian Phytopath, 56:191- 193.

Tripathi, A.K. (2005). Efficacy of fungicides and plant products against stem gall disease of coriander. J Myc Pl Path, 35:388-389

Tripathi, A.K., Bartaria, A.M., Pandya, R.K. and Tripathi, M.L. (2002). Effect of cultural practices on stem gall disease of coriander. Ann Agric Res, 23:171-173.

VermaPreeti, Meena D.S., Jadon Chaman and Singh D.K. (2017). Effect of International Journal of Seed Spices.

\section{How to cite this article:}

Preeti Verma, Mohan Lal Yadav, C.B. Meena and Yadav, D.L. 2019. Stem Gall Disease of Coriander: Causes and Integrated Management. Int.J.Curr.Microbiol.App.Sci. 8(11): 25732580. doi: https://doi.org/10.20546/ijcmas.2019.811.297 